\title{
DIDACTICS: METHODOLOGICAL BASIS OF MOTOR LEARNING IN CHILDREN AND ADOLESCENTS
}

\author{
Oleg Khudolii ${ }^{A B C D}$, Sergii Iermakov ${ }^{2 A B C D}$, Pavol Bartik ${ }^{3 A B C D}$ \\ ${ }^{1}$ H. S. Skovoroda Kharkiv National Pedagogical University \\ ${ }^{2}$ Gdansk University of Physical Education and Sport \\ ${ }^{3}$ Matej Bel University \\ Authors' Contribution: A - Study design; B - Data collection; C - Statistical analysis; D - Manuscript Preparation; E - Funds Collection
}

DOI: $10.17309 / \mathrm{jltm} .2020 .1 .01$

\begin{abstract}
The purpose of the study was to determine the impact of knowledge considered as a methodological basis of motor learning on the effectiveness of motor skills development in children and adolescents.

Materials and methods. Young gymnasts aged 7-13 participated in the experiment. At the first stage - young gymnasts aged 8 (16 groups of 6 people each). At the second stage - young gymnasts aged 8 (3 groups of 6 people each), young gymnasts aged 13 (2 groups of 6 people each). Both philosophical and general scientific research methods were used to solve the tasks set, among which were: dialectical method, systems approach, modeling, pedagogical experiment organized according to the scheme of a $2^{\mathrm{k}}$ factorial experiment.

Results. A positive effect of learning depends on the consistent solution of learning tasks and rational application of methods. This is indicated by the following: firstly, the total impact of factors reduces the number of repetitions when teaching young gymnasts a side handspring (by 23 repetitions), secondly, the total interaction increases the duration of training by 9 repetitions. Obviously, studying the decomposition of learning tasks can improve the effectiveness of learning in general.

Conclusions. The learning process structure is most influenced by the conclusions of the theory of functional systems $(43 \%, p<0.001)$, the theory of movement construction $(41 \%, p<0.001)$, and the theory of management of knowledge acquisition, formation of actions and concepts $(2.6 \%, p<0.05)$. A positive effect of learning depends on the consistent solution of learning tasks and rational application of methods.
\end{abstract}

Keywords: motor learning, methodological basis, children, adolescents.

\section{Introduction}

Modern pedagogy and psychology extensively study the laws of "verbal learning", which is a special kind and depends on the specific nature of human reasoning (Talyzina, 2002, 2004), and very little attention is paid to studying the laws of "motor learning" (Haverdovsky, 2007; Bohen, 2020).

The theories that are considered as a methodological basis of motor learning include: Pavlov's reflex theory, Anokhin's theory of functional systems, Bernstein's theory of movement construction, Halperin's theory of management of knowledge acquisition, formation of actions and concepts (Khudolii, 2010).

I.P. Pavlov's theory is the basis of studying conditioned reflexes in humans. The formation of motor skills was

(C) Oleg Khudolii, Sergii Iermakov, Pavol Bartik, 2020. physiologically substantiated in the light of the theory of conditioned reflexes by O. M. Krestovnikov (1951). According to this concept, the basis of the motor skill is a conditioned reflex, simple or complex. Motor reaction is formed during the repeated combination of a conditioned stimulus (stimulus, conditioned signal) and the required reaction - movement. Reinforcement is a positive motor experience and the teacher's praise. As a result of repetition, a dynamic stereotype is formed in the motor area of the cerebral hemispheres (Krestovnikov, 1951; Krestovnikov, \& Vasileva, 1955).

In the formation of conditioned reflexes, it is important to follow all the conditions under which learning takes place. The final conditioned effect is not only the result of a conditioned stimulus. Excitation from a conditioned stimulus forms a synthetic unity with the excitations prepared by a set of previous stimuli, in the form of a system of prestart excitations. The latter themselves do not cause a conditioned reaction, but determine its form and extent of detection (Anokh- 
in, 1979, 1980). A change in the sequence of conditioned reflex activity can lead to a negative result, as pointed out by Anokhin $(1979,1980)$. In addition, the dynamic stereotype, according to Anokhin, in its essence and technique of obtaining is a conservative formation of the nervous system, which, once formed, manifests itself even against the reality. All processes of dynamic stereotypy are based on the principle of anticipatory excitation. Or, as Maznichenko (1984) points out, a motor skill emerges on the basis of a conditioned reflex, provides prediction of the future, its anticipatory reflection.

The classical reflex theory continues to influence the study of behavioral adaptation in addressing three key issues: (1) under what conditions does learning take place, (2) what associative structures are involved, and (3) how does it affect behavior? (Clark, 2004; Honey, Iordanova, \& Good, 2014).

One can assume that when constructing the process of teaching motor actions, it is necessary to take into account: (1) a motor skill - a system of simpler skills, teaching should be based on the acquired experience so that previously learned movements are part of more complex ones; (2) when teaching exercises, external conditions should be kept constant, as they are a system of prestart excitations; (3) the effectiveness of motor skills development depends on the completeness of impact on the analyzers, as well as the speech areas of the cerebral hemispheres, as afferent synthesis is the basis of movement.

The theory of functional systems was developed in the papers of Anokhin $(1979,1980)$. The functional system is an integrated unit of the whole body, which develops dynamically to achieve any adaptive activity and always selectively unites special central-peripheral formations based on cyclic relationships. The functional system has a branched morphophysiological apparatus, which provides through its own patterns the effect of both homeostasis and self-regulation. It uses a variety of subtle mechanisms of integration and directs all intermediate processes to obtain the final adaptive effect and its evaluation (Anokhin, 1979, 1980). The importance of the theory of functional systems in studying behavioral responses is indicated in the papers by Egiazaryan, and Sudakov (2007), Rusalov (2018).

Anokhin $(1979,1980)$ substantiated the concept of "action acceptor" and "reverse afferentation". According to him, the "acceptor of action results" is intended for perceiving information about the obtained results and comparing it with the parameters of the results that have developed during the action of a conditioned stimulus. Further, Anokhin notes that reverse afferentations arising during any motor act should be divided into two different categories: a) movement-directing and b) resultative afferentations. While the former afferentation is represented primarily by proprioceptive impulses from the muscles bringing about the movement, the latter is always complex and encompasses all the afferent features that characterize the result of the performed movement. Another important point is that the vegetative component of conditioned response is organic components of the part of any integral response.

One can assume that the process of teaching motor actions should be based on the following principles: (1) sufficient level of performance, a condition for motor skills development, as the vegetative component is a part of integral response; (2) when teaching movements, it is necessary to take into account more fully all the parameters that together determine the afferent information about the obtained results.

Bernstein's theory of movement construction. Of importance is the conclusion of Bernstein (1966) that as soon as any group of coordination corrections switches from the highest level to the background one, the most adequate for it in quality and composition of its corrections, so it becomes automatic and performed with minimal conscious involvement. In each movement we must distinguish: (1) its meaning structure and (2) its motor composition. The meaning structure stems entirely from the essence of a task and determines the leading level of construction. Motor composition is determined not only by a task, but also by its collision with a person's motor abilities (Bernstein, 1966). Filatova, Eskov, Filatov, and Ilyashenko (2017) point out the importance of Bernstein's theory for studying behavioral responses.

Thus: (1) the construction of the process of teaching motor actions requires a biomechanical analysis of the exercise, in order to determine spatial, temporal and strength characteristics of the movement, which will make it possible to assess a sufficient level of fitness and optimally build the process of motor training; (2) the circular principle of correction suggests that the ability to control movements characterizes the quality of corrections and defines the effectiveness of learning, so the previous development of the ability to control movements should positively influence the learning process.

From the perspective of the activity theory, Halperin and his collaborators developed a theory of gradual formation of actions and concepts, management of the process of knowledge acquisition. In this theory, the mode of action and the image of environment where the action takes place unite into a single element, on the basis of which the action is managed, called the "oriented basis of action (OBA)". The OBA is the image of the system of conditions a person actually relies on when performing an action. The OBA is not identical to the conditions of an action that really, objectively exists, firstly, because the OBA is a subjective category existing in a person's consciousness or subconsciousness as a reflection of the action conditions; secondly, because a person may completely or incompletely know these conditions, more or less adequately assess them. The success of an action depends on the completeness of the OBA and its compliance with objective conditions of task solving (Halperin, 1958, 1967, 1968).

The concepts of Halperin's theory helped to explain many phenomena in learning motor actions, to substantiate effective methods of teaching and organization of the learning process. All this allows us to accept this theory as an element of the methodological basis of the theory of teaching motor actions (Halperin, 1968; Bohen, 1985).

The implementation of the theory of gradual formation of mental actions can be effective in the process of giving an idea of movement during all stages of learning.

The purpose of the study was to determine the impact of knowledge considered as a methodological basis of motor learning on the effectiveness of motor skills development in children and adolescents. 


\section{Materials and methods}

\section{Study participants}

Young gymnasts aged 7-13 participated in the experiment. At the first stage - young gymnasts aged 8 (16 groups of 6 people each). At the second stage - young gymnasts aged 8 (3 groups of 6 people each), young gymnasts aged 13 (2 groups of 6 people each). The young athletes and their parents were informed about the features of the experiment and gave their consent to participate in it.

\section{Study organization}

Both philosophical and general scientific research methods were used to solve the tasks set, among them were: dialectical method, systems approach, modeling, pedagogical experiment organized according to the scheme of a $2^{\mathrm{k}}$ factorial experiment.

The experiment was conducted in two stages. At the first stage, the study determined the knowledge and its impact on the effectiveness of the process of teaching physical exercises.

To achieve this purpose, a $2^{4}$ factorial design was used. The study determined the effectiveness of the learning process structure depending on a didactic analysis of the basics of the reflex theory $\left(x_{1}\right)$, the basics of the theory of functional systems $\left(x_{2}\right)$, the basics of the theory of movement construction $\left(x_{3}\right)$, the basics of the theory of gradual formation of mental actions $\left(x_{4}\right)$. Each factor varied in the qualitative level of "used" (+) or "not used" (-) (see Tables 1, 2).

At the second stage, the young gymnasts aged 8 learned an arch press to headstand. Training was conducted using the method of algorithmic instructions. In the first group, training was conducted after heavy loads, when performance was low; in the second - when performance was high; in the third - taking into account information processes about the
Table 2. Didactic analysis of theories that explain the process of learning movements

\begin{tabular}{|c|c|c|c|c|c|}
\hline No. & Learning task & $x_{1}$ & $x_{2}$ & $x_{3}$ & $x_{4}$ \\
\hline 1. & $\begin{array}{l}\text { Give an idea of the movement } \\
\text { technique }\end{array}$ & + & + & & + \\
\hline 2. & $\begin{array}{l}\text { Develop motor abilities necessary for } \\
\text { learning movements }\end{array}$ & & + & & \\
\hline 3. & $\begin{array}{l}\text { Teach movements without which it is } \\
\text { impossible to perform the exercise }\end{array}$ & & & + & \\
\hline 4. & $\begin{array}{l}\text { Teach the abilities to control } \\
\text { movements }\end{array}$ & & + & + & \\
\hline 5. & Teach preliminary exercises & + & + & & \\
\hline 6. & Teach the whole exercise & + & + & + & + \\
\hline 7. & Ensure a high level of performance & & + & & \\
\hline 8. & Teach the exercise in combination & + & & + & \\
\hline
\end{tabular}

adaptive reactions of the body of young gymnasts. Young gymnasts aged 12-13 learned a back uprise on bars, grand swings forward and backward on rings.

\section{Statistical analysis}

The obtained experimental material was processed using statistical analysis software (SPSS 20). Analysis of variance, factor and regression analyses were performed.

\section{Results}

The analysis of data using a special program made it possible to obtain a dependence of the effectiveness of different variants of teaching a side handspring on the didactic analysis of the above theories. This dependence is described by the equation:

$$
\begin{aligned}
\mathrm{Y}= & 46.187-1.062 x_{1}-9.812 x_{2}+1.687 x_{1} x_{2}-9.562 x_{3}+ \\
& +1.437 x_{1} x_{3}+4.437 x_{2} x_{3}-2.437 x_{4}+1.063 x_{2} x_{4}
\end{aligned}
$$

\begin{tabular}{|c|c|c|c|c|}
\hline \multirow{2}{*}{ Experiments } & Reflex theory & $\begin{array}{c}\text { Theory of functional } \\
\text { systems }\end{array}$ & $\begin{array}{c}\text { Theory of movement } \\
\text { construction }\end{array}$ & $\begin{array}{c}\text { Theory of gradual formation } \\
\text { of mental actions }\end{array}$ \\
\hline & $x_{1}$ & $x_{2}$ & $x_{3}$ & $x_{4}$ \\
\hline 1 & - & - & - & - \\
\hline 2 & + & - & - & - \\
\hline 3 & - & + & - & - \\
\hline 4 & + & + & - & - \\
\hline 5 & - & - & + & - \\
\hline 6 & + & - & + & - \\
\hline 7 & - & + & + & - \\
\hline 8 & + & + & + & - \\
\hline 9 & - & - & - & + \\
\hline 10 & + & - & - & + \\
\hline 11 & - & + & - & + \\
\hline 12 & + & + & - & + \\
\hline 13 & - & - & + & + \\
\hline 14 & + & - & + & + \\
\hline 15 & - & + & + & + \\
\hline 16 & + & + & + & + \\
\hline
\end{tabular}

Table 1. Experimental conditions. The $2^{4}$ factorial design 
The analysis of regression coefficients showed that the total impact of knowledge about the learning process influences the effectiveness of developing a program for motor skills formation (Table 2).

The results of analysis of variance of the effectiveness of different structures of teaching young gymnasts aged 8 a side handspring revealed that the learning process structure is most influenced by the conclusions of the theory of functional systems $(43 \%, p<0.001)$, the theory of movement construction $(41 \%, p<0.001)$, the theory of management of knowledge acquisition, formation of actions and concepts $(2.6 \%, p<0.05)$ (Table 3$)$.

Thus, the process of learning motor actions is indirectly influenced by knowledge obtained from psychology, physiology, biomechanics. Indirectness displays itself in the need for didactic analysis of the theoretical structure formed as a result of the study.

The study shows that various structures of teaching movements are only an inference made on the basis of the above-mentioned theories. Their implementation is an objectively existing process that requires special research. Didactic studies make it possible to formulate learning tasks and define the means needed to address them. The reflex theory, the theory of functional systems, the theory of movement construction do not consider learning tasks and do not define the content of learning, but the findings of the study explain the need to consider the learning tasks of exercises.

A positive effect of learning depends on the consistent solution of learning tasks and rational application of meth-
Table 3. The results of analysis of variance of the effectiveness of different structures of teaching young gymnasts aged 8 a side handspring

\begin{tabular}{crrcc}
\hline $\begin{array}{c}\text { Source of } \\
\text { change }\end{array}$ & $\begin{array}{c}\text { Sum of } \\
\text { squares }\end{array}$ & $\begin{array}{c}\text { Mean } \\
\text { square }\end{array}$ & $\begin{array}{c}\text { Mean } \\
\text { square } \\
\text { ratio }\end{array}$ & $\begin{array}{c}\text { Level of } \\
\text { influence, } \\
\%\end{array}$ \\
\hline$x_{1}$ & 18.062 & 18.062 & 3.518 & 0.5 \\
$x_{2}$ & 1540.56 & 1540.56 & 300.087 & 43.2 \\
$x_{1} x_{2}$ & 45.562 & 45.562 & 8.875 & 1.278 \\
$x_{3}$ & 1463.06 & 1463.06 & 284.991 & 41.046 \\
$x_{1} x_{3}$ & 33.062 & 33.062 & 6.44 & 0.927 \\
$x_{2} x_{3}$ & 315.062 & 315.062 & 61.371 & 8.839 \\
$x_{4}$ & 95.062 & 95.062 & 18.517 & 2.667 \\
$x_{2} x_{4}$ & 18.062 & 18.062 & 3.518 & 0.506 \\
\hline
\end{tabular}

ods. This is indicated by the following: firstly, the total impact of factors reduces the number of repetitions when teaching young gymnasts a side handspring (by 23 repetitions), secondly, the total interaction increases the duration of training by 9 repetitions. Obviously, studying the decomposition of

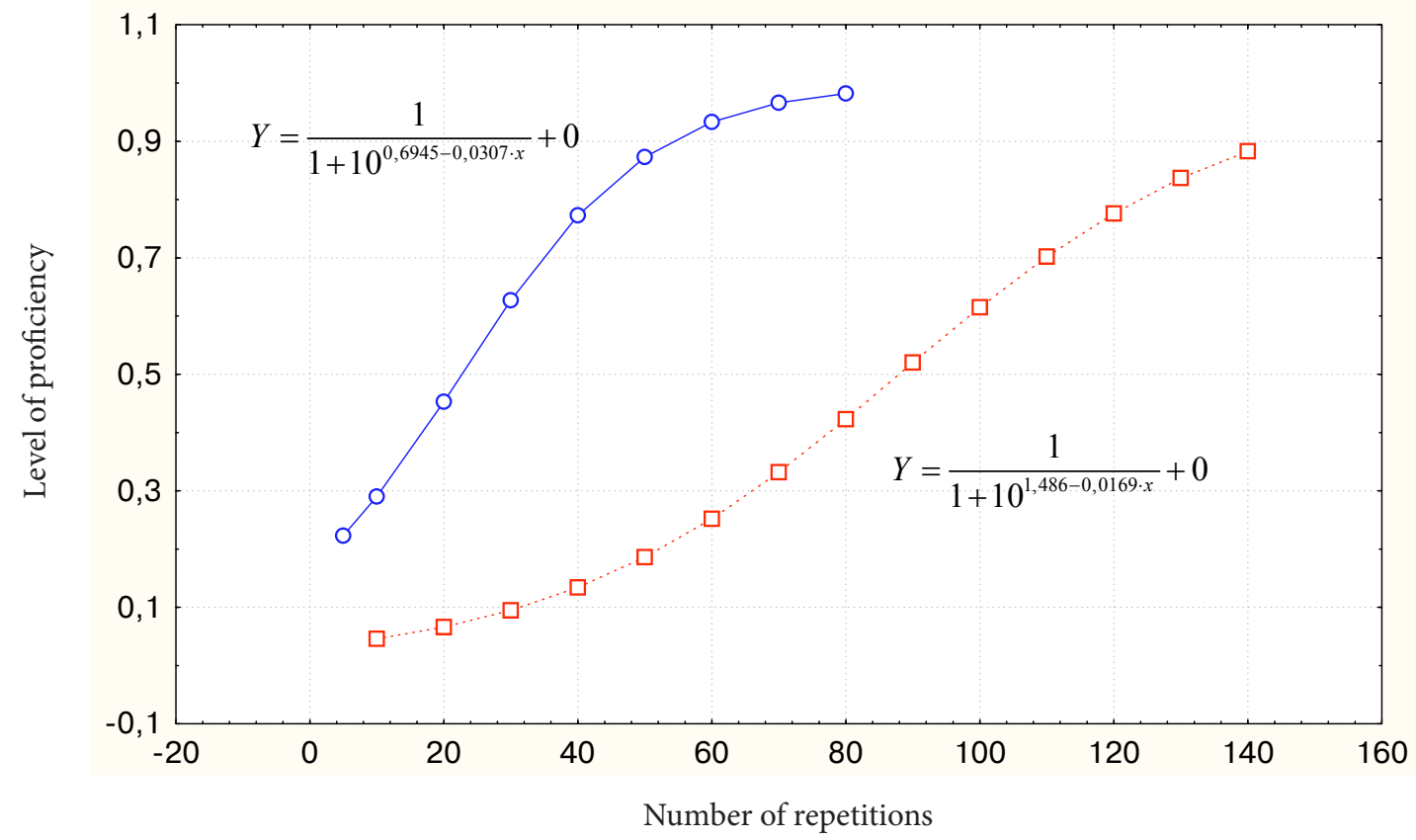

Fig. 1. Dependence of the level of proficiency in arch press to headstand and handstand on the level of performance of young gymnasts: $\mathrm{a}$ - increase in the level of proficiency in arch press to headstand $(\mathrm{Y})$ of young gymnasts, depending on the number of repetitions, training was conducted when performance was high; $b$ - increase in the level of proficiency in arch press to headstand $(\mathrm{Y})$ of young gymnasts, depending on the number of repetitions $(\mathrm{X})$, training was conducted when performance was low 


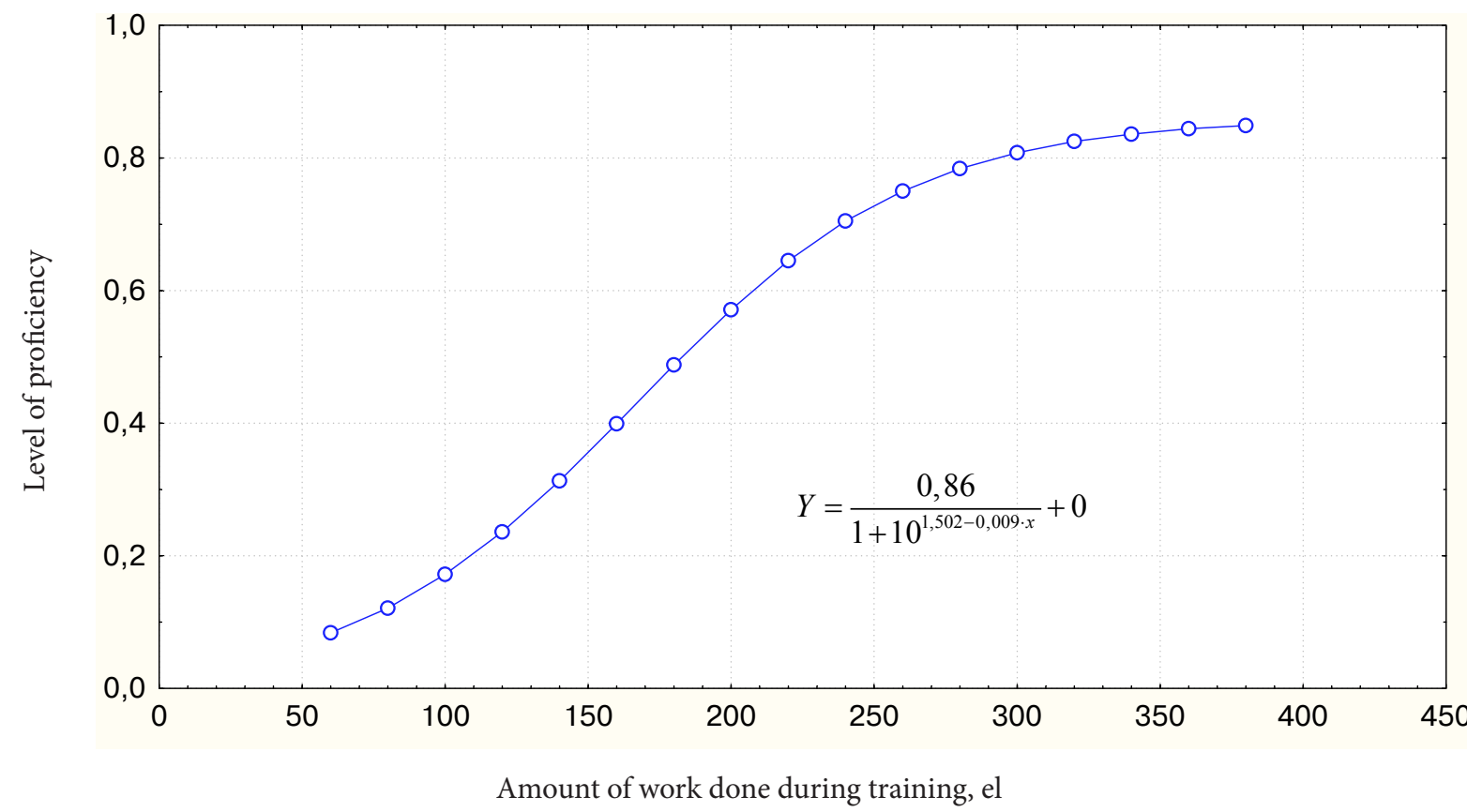

Fig. 2. Increase in the level of proficiency in back uprise of young gymnasts aged 13, depending on the increase in performance

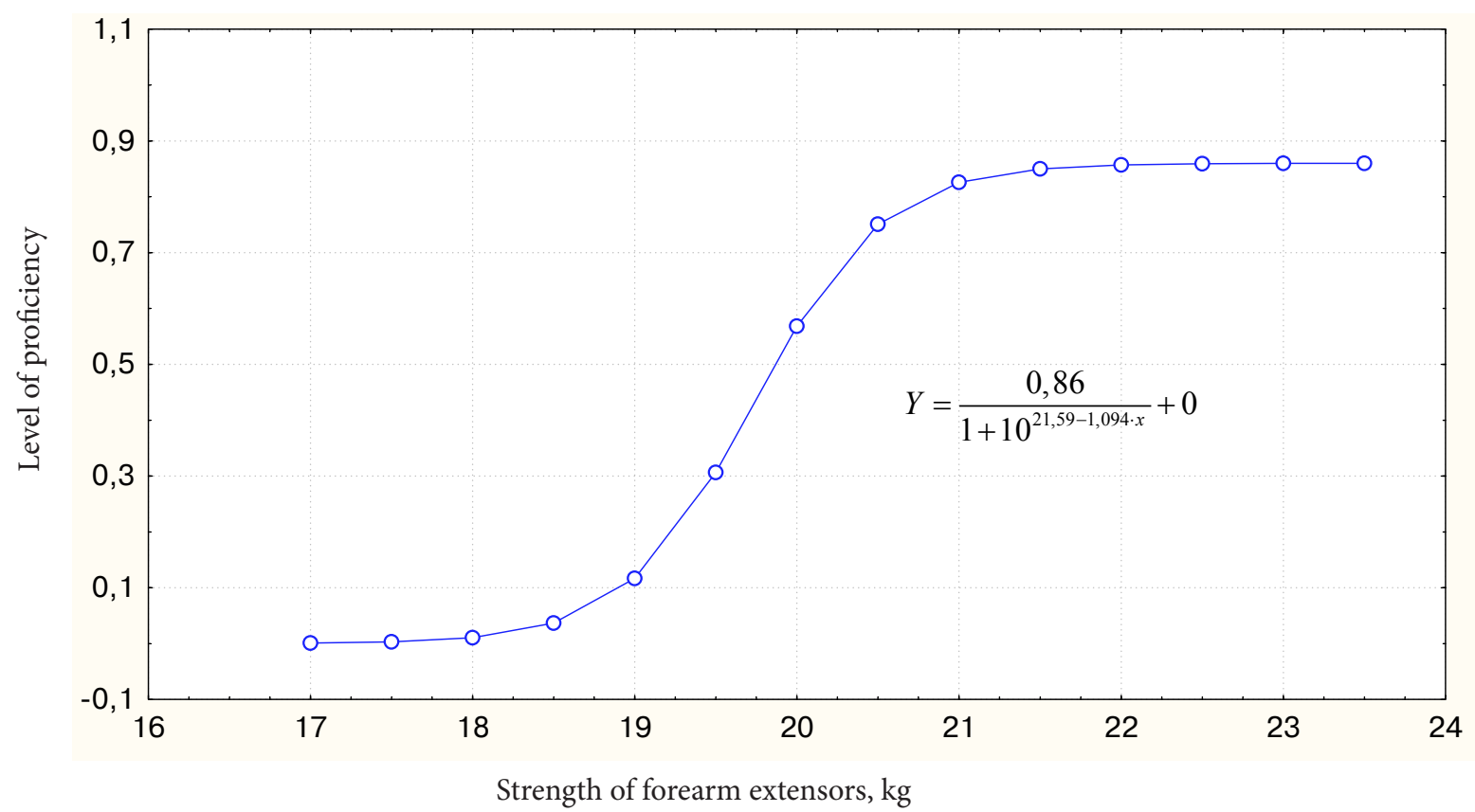

Fig. 3. Increase in the level of proficiency in back uprise of young gymnasts aged 13, depending on the increase in the strength of forearm extensors

learning tasks can improve the effectiveness of learning in general.

The analysis of the results of the second stage of the experiment showed that young gymnasts aged 8 of the first group learned the exercise for $128 \pm 8$ repetitions; of the second group - for $57 \pm 6$; of the third group - for $13 \pm 1$ repetitions (taking into account the number of repetitions of the whole exercise). The differences between the groups are significant $(\mathrm{p}<0.001)$ and explained by the decomposition of learning tasks by $90 \%$. The dependence of the level of proficiency in arch press to headstand and handstand on the level of performance of young gymnasts aged 8 is given in Fig. 1.

The studies showed that teaching gymnasts aged 1213 complex movements (back uprise on bars, grand swings 


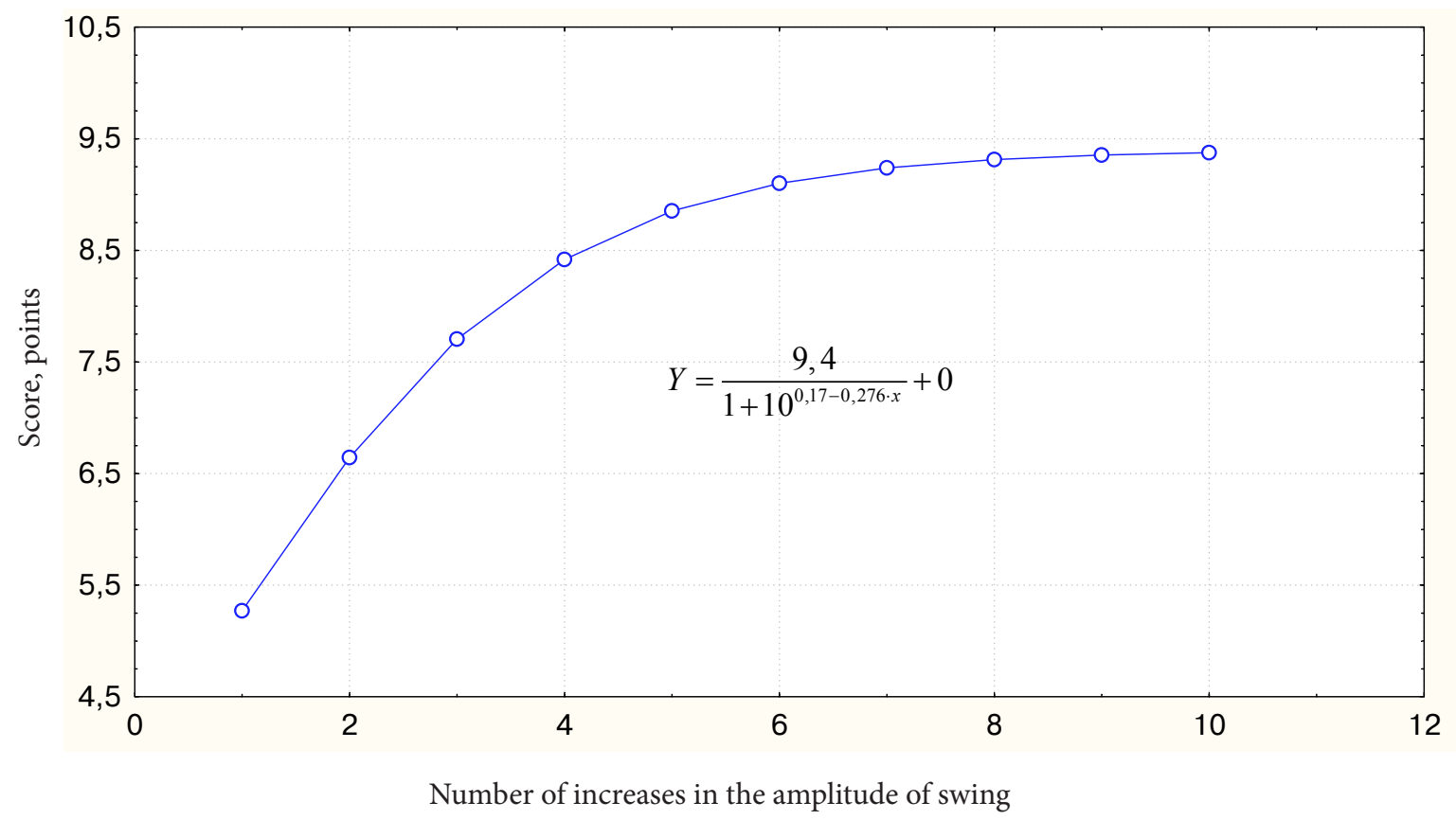

Fig. 4. Increase in the score for performing "back uprise" by young gymnasts aged 13, depending on the ability to perform swings with a minimum increase in the amplitude

forward and backward on rings) significantly accelerates if conducted on the basis of information processes about developing strength, about increasing the level of differentiation of spatial, temporal and strength characteristics of the movement being studied, and also taking into account the performance dynamics (Fig. 1, 2, 3, 4). It is obvious that the basis of effective teaching of movements to young gymnasts is the implementation of learning tasks, taking into account the patterns of adaptation processes of the body of young athletes.

\section{Discussion}

The study assumed that the knowledge of Pavlov's reflex theory, Anokhin's theory of functional systems, Bernstein's theory of movement construction, Halperin's theory of management of knowledge acquisition, formation of actions and concepts is the basis for optimizing the process of motor skills development in children and adolescents. The reflex theory, the theory of functional systems, the theory of movement construction do not consider learning tasks and do not define the content of learning, but the findings of the study explain the need to consider the learning tasks of exercises. The knowledge of the theories of functional systems and movement construction has the largest influence on optimizing motor skills development. The influence of Pavlov's reflex theory is reduced due to the fact that Anokhin's theory of functional systems and Bernstein's theory of movement construction intersect in many respects and can be combined into an associative-reflex theory. According to Clark (2004), Honey, Iordanova, and Good (2014), the classical reflex theory continues to influence the study of behavioral adaptation.

Studies showed that the impossibility to learn motor actions results from a poor functional state of the neuromuscu- lar and cardiovascular systems and, consequently, a low level of performance of young gymnasts aged 7-10. The influence of the young gymnasts' level of performance on the process of learning an arch press to headstand and handstand is clearly shown in Fig. 1. So the possibility to learn a headstand increases significantly if training begins when performance is high. Learning exercises after moderate loads is faster than after heavy loads. This confirms the findings about the influence of training loads on motor skills development, so after moderate loads the stage of motor skills development is the longest ( $p=0.4-0.5 ; 0.6-0.7)$, after heavy loads the initial stage of motor skill development becomes longer $(p=0.1$ 0.3 ). Learning exercises at the stages of motor skill development $(p=0.6-0.7)$ and completion of learning $(\mathrm{p}=0.8-1.0)$ after heavy loads is the same as after moderate loads. With the achievement of the level of proficiency $p=0.6$, it is possible to learn gymnastic exercises after heavy loads (Khudolii, 1983).

The study results show that the increase in performance of young gymnasts aged 13 has a positive impact on learning a back uprise. The speed of learning increases by 2-3 times compared to training conducted when the level of performance is low (Fig. 2).

Ivashchenko, Nosko, M., Nosko, Y., and Chernenko (2019), Ivashchenko, Khudolii, Iermakov, Chernenko, and Honcharenko (2018) also point out the importance of regulating the modes of exercises during motor skills development in junior school students; in middle school students - Kapkan, Khudolii, and Bartik (2019), Khudolii, Kapkan, Harkusha, Marchenko, and Veremeenko (2020).

The regression analysis between the score, the level of proficiency in movements, and the maximal strength of forearm extensors revealed that ensuring the increase in strength from training to training helps to improve the score for the 
Table 4. Tasks, teaching methods and their substantiation

\begin{tabular}{|c|c|c|c|}
\hline Learning task & Field of knowledge & Methods & Substantiated by \\
\hline $\begin{array}{l}\text { Give an idea of the movement } \\
\text { technique }\end{array}$ & $\begin{array}{l}\text { Theory of gradual formation of mental } \\
\text { actions. Reflex theory. } \\
\text { Theory of functional systems }\end{array}$ & $\begin{array}{l}\text { Method of giving } \\
\text { knowledge about the } \\
\text { movement technique }\end{array}$ & $\begin{array}{l}\text { Menkhin, and Shlemin } \\
(1979)\end{array}$ \\
\hline $\begin{array}{l}\text { Develop motor abilities necessary } \\
\text { for learning movements }\end{array}$ & $\begin{array}{l}\text { Theory of functional systems. } \\
\text { Theory of body adaptation to physical } \\
\text { loads }\end{array}$ & $\begin{array}{l}\text { Method of concentrated } \\
\text { and supportive loads. } \\
\text { Method of combination }\end{array}$ & $\begin{array}{l}\text { Verkhoshanskyi (1988), } \\
\text { Diachkov (1966), } \\
\text { Yu. Menkhin (1969) }\end{array}$ \\
\hline $\begin{array}{l}\text { Teach the starting } \\
\text { and ending positions }\end{array}$ & Reflex theory & Method of decomposition & Maznichenko (1976) \\
\hline $\begin{array}{l}\text { Teach actions without which it is } \\
\text { impossible to } \\
\text { perform the exercise }\end{array}$ & Theory of movement construction & $\begin{array}{l}\text { Method of solving partial } \\
\text { tasks }\end{array}$ & $\begin{array}{l}\text { Shlemin, and Petrov } \\
\text { (1977) } \\
\begin{array}{l}\text { Menkhin, and Shlemin } \\
(1979)\end{array}\end{array}$ \\
\hline $\begin{array}{l}\text { Teach the abilities to } \\
\text { control movements }\end{array}$ & $\begin{array}{l}\text { Theory of functional systems. Theory } \\
\text { of movement construction }\end{array}$ & $\begin{array}{l}\text { Method of immediate } \\
\text { and current information } \\
\text { about the accuracy of } \\
\text { movements }\end{array}$ & $\begin{array}{l}\text { Farfel (1975), Shlemin } \\
(1968) \text { Orlov (1969) }\end{array}$ \\
\hline Teach preliminary exercises & $\begin{array}{l}\text { Reflex theory. } \\
\text { Theory of functional systems }\end{array}$ & $\begin{array}{l}\text { Method of preliminary } \\
\text { exercises }\end{array}$ & $\begin{array}{l}\text { Maznichenko (1976) } \\
\text { Shlemin, and Petrov } \\
(1977)\end{array}$ \\
\hline Teach the whole exercise & $\begin{array}{l}\text { Reflex theory. } \\
\text { Theory of functional systems. } \\
\text { Theory of movement construction }\end{array}$ & Holistic method & $\begin{array}{l}\text { Yananis (1969) } \\
\text { Menkhin, and Shlemin } \\
(1979)\end{array}$ \\
\hline Ensure a high level of performance & $\begin{array}{l}\text { Theory of functional systems. Theory } \\
\text { of body adaptation to physical loads }\end{array}$ & $\begin{array}{l}\text { Method of variability of } \\
\text { training loads }\end{array}$ & $\begin{array}{l}\text { Shlemin (1968) } \\
\text { Khudolii (1985) }\end{array}$ \\
\hline Teach the exercise in combination & $\begin{array}{l}\text { Reflex theory. } \\
\text { Theory of movement construction }\end{array}$ & $\begin{array}{l}\text { Method of standard } \\
\text { exercise. } \\
\text { Method of variable } \\
\text { exercise }\end{array}$ & $\begin{array}{l}\text { Yananis (1969) } \\
\text { Maznichenko (1976) } \\
\text { Menkhin, and Shlemin } \\
(1979)\end{array}$ \\
\hline
\end{tabular}

exercise and increase the level of proficiency in the movement (Fig. 3). The analysis of the increase in the proficiency level in back uprise of young gymnasts aged 13, depending on the increase in the strength of forearm extensors showed that the optimal level of strength development of forearm extensors is a maximal strength of $20-21 \mathrm{~kg}$ (exercise was considered performed if the score was more than 8 points) (Fig. 3 ).

The study results show that one of the conditions that facilitate motor skills formation is the development of kinesthetic sensations that ensure the necessary accuracy of movements in space, time and a degree of muscular effort (Farfel, 1975; Khudolii, O., \& Iermakov, 2011). Studies show that there is a relationship between the proficiency level and the error in movement control in space and the differentiation of muscular effort before exercises, which is described by the logistic function (Fig. 4). This indicates that the initial level of error in movement control affects the level of proficiency in exercises, the higher the muscle sensitivity before exercises, the higher the level of proficiency.

The analysis of the study results points to the need to decompose the purposes and tasks of motor skills development. So, the level of strength development, muscle sensitivity, and the training mode significantly influence the process of learning motor actions. This fact allows us to formulate the following learning tasks: 1) to develop motor abilities necessary for learning movements; 2) to teach the abilities to control movements; 3) to ensure a high level of performance. Studies of the biomechanical structure of movement allow us to formulate the following learning tasks: 1) to teach actions without which it is impossible to perform the exercise; 2 ) to teach preliminary exercises (Table 4).

\section{Conclusions}

The learning process structure is most influenced by the conclusions of the theory of functional systems $(43 \%$, $p<0.001)$, the theory of movement construction $(41 \%$, $p<0.001)$, and the theory of management of knowledge acquisition, formation of actions and concepts $(2,6 \%, p<0.05)$. A positive effect of learning depends on the consistent solution of learning tasks and rational application of methods.

Based on a factorial experiment, it was found that the effectiveness of learning motor actions is determined by the decomposition of learning and training tasks based on the objective adaptive reactions of the body of young gymnasts. The training solves the tasks of developing motor abilities, increasing the level of special motor and functional fitness of young gymnasts to master gymnastic exercises. The procedure for solving tasks and selecting educational and training tasks is the following: 1) developing motor abilities, increasing the level of young gymnasts' functional fitness; 2) teach- 
ing the starting and ending positions; 3) teaching actions without which it is impossible to perform the exercise being studied; 4) teaching the abilities to control movements, teaching preliminary exercises; 5) teaching the whole exercises; 6) increasing the level of young gymnasts' functional fitness; 7) teaching exercises in combination.

\section{Conflict of interest}

The authors declare that there are no conflicts of interest.

\section{References}

Talyzina, N. F. (2002). Development by P.Ya. Galperin of the activity approach in psychology. Voprosy Psikhologii, (5), 42-49+159. Retrieved from www.scopus.com

Talyzina, N. (2004). Activity theory of learning as the base of new type of education. International journal of psychology, 39(5-6), 265-265

Haverdovsky, Yu.K. (2007). Obuchenie sportivnym uprazhneniyam. Biomekhanika. Metodologiya. Didaktika. Fizkul'tura i sport, 912. (in Russian)

Bogen, M.M. (2020). Fizicheskoe vospitanie i sportivnaya trenirovka: obuchenie dvigatel'nym deystviyam: Teoriya $i$ metodika. URSS, 226. (in Russian)

Farfel', B.C. (1975). Upravlenie dvizheniyami v sporte.Fizkul'tura i sport, 226. (in Russian)

Khudolii, O., \& Iermakov, S. (2011). Zakonomirnosti protsesu navchannia yunykh himnastiv. Teoriâ ta Metodika Fizičnogo Vihovannâ, (5), 3-18, 35. https://doi.org/10.17309/tmfv.2011.5.707 (in Ukrainian)

Khudolii, O.M. (2010). Analiz vkladu fiziolohichnykh ta psykholohichnykh teorii formuvannia rukhovykh navychok u rozvytok teorii navchannia himnastychnym vpravam. Pedahohika, psykholohiia ta medyko-biolohichni problemy fizychnoho vykhovannia i sportu, (6), 136-141. (in Ukrainian)

Clark, R. E. (2004). The classical origins of Pavlov's conditioning. Integrative Physiological \& Behavioral Science, 39(4), 279-294. https://doi.org/10.1007/BF02734167

Honey, R. C., Iordanova, M. D., \& Good, M. (2014). Associative structures in animal learning: Dissociating elemental and configural processes. Associative Perspectives on the Neurobiology of Learning, 108, 96-103. https://doi.org/10.1016/j.nlm.2013.06.002

Egiazaryan, G. G., \& Sudakov, K. V. (2007). Theory of Functional Systems in the Scientific School of P.K. Anokhin. Journal of the History of the Neurosciences, 16(12), 194-205. https://doi.org/10.1080/09647040600602805

Rusalov, V. (2018). Functional systems theory and the activity-specific approach in psychological taxonomies. Philosophical Transactions of the Royal Society B: Biological Sciences, 373(1744), 20170166. https://doi.org/10.1098/rstb.2017.0166

Filatova, O. E., Eskov, V. V., Filatov, M. A., \& Ilyashenko, L. K. (2017). Statistical instability phenomenon and evaluation of voluntary and involuntary movements. Russian Journal of Biomechanics, 21(3), 224-232. Scopus. https://doi.org/10.15593/RJBiomech/2017.3.03
Krestovnikov, A.N., \& Vasil'eva, V.V. (1955). O protekanii korkovykh nervnykh protsessov u sportsmenov. Teoriya $i$ praktika fiz. kul'tury, XVIII(1), 52-61. (in Russian)

Krestovnikov, A.N. (1951). Ocherki po fiziologii fizicheskikh uprazhneniy. M.: Fizkul'tura i sport, 532. (in Russian)

Anokhin, P.K. (1979). Sistemnye mekhanizmy vysshey nervnoy deyatel'nosti: Izbrannye trudy. M.; Nauka, 14-100, 353-366. (in Russian)

Anokhin, P.K. (1980). Funktsional'naya sistema: Uzlovye voprosy teorii funktsional'noy sistemy. M.: Nauka, 154-180. (in Russian)

Maznichenko, V.D. (1984). Metodologicheskie predposylki k ponimaniyu sushchnosti i mekhanizmov dvigatel'nykh navykov. Teoriya i praktika fiz. kul'tury, (7), 49-51. (in Russian)

Bernshteyn, N.A. (1966). Ocherki po fiziologii dvizheniy $i$ fiziologii aktivnosti. M.: Meditsina, 350. (in Russian)

Gal'perin, P.Ya. (1958). Tipy orientirovki i tipy formirovaniya deystviy i ponyatiy. Doklady APN RSFSR,(2). (in Russian)

Gal'perin, P.Ya. (1967). K teorii programmirovannogo obucheniya. M.: Znanie, 44. (in Russian)

Gal'perin, P.Ya. (1968). Formirovanie znaniy i umeniy na osnove teorii poetapnogo usvoeniya umstvennykh deystviy. M.: Izd. MGU, 135. (in Russian)

Bogen, M.M. (1985). Obuchenie dvigatel'nym deystviyam. M.: Fizkul'tura i sport, 193. (in Russian)

Khudolii, O. (1983). Effektivnost' obucheniya gimnasticheskim uprazhneniyam detey 8-10 let pri razlichnykh rezhimakh trenirovochnykh zanyatiy: Avtoref. dis. ... kand. ped. nauk: 13.00.04. M.: NII FDiP APN SSSR, 23. (in Russian)

Khudolii, O., Kapkan, O., Harkusha, S., Marchenko, S., \& Veremeenko, V. (2020). Motor Skills Development: Optimization of Teaching Boys Aged 15 Press Headstand and Handstand. Teoriâ ta Metodika Fìzičnogo Vihovannâ, 20(1), 42-48. https://doi.org/10.17309/tmfv.2020.1.06

Ivashchenko, O., Nosko, M., Nosko, Y., \& Chernenko, S. (2019). Pattern Recognition: Description of Modes of Teaching Boys Aged 7 Throwing a Small Ball at a Vertical Target. Teoriâ ta Metodika Fizičnogo Vihovannâ, 19(3), 130-138. https://doi.org/10.17309/tmfv.2019.3.04

Kapkan, O., Khudolii, O., \& Bartik, P. (2019). Motor Skills Development: Optimization of Teaching Boys Aged 14. Teoriâ ta Metodika Fizičnogo Vihovannâ, 19(3), 148-155. https://doi.org/10.17309/tmfv.2019.3.06

Ivashchenko, O., Khudolii, O., Iermakov, S., Chernenko, S., \& Honcharenko, O. (2018). Full factorial experiment and discriminant analysis in determining peculiarities of motor skills development in boys aged 9. Journal of Physical Education and Sport, 18(s4), 1958-1965. https://doi.org/10.7752/jpes.2018.s4289

Menkhin, A.V., \& Shlemin A.M. (1979). Metodika obucheniya gimnasticheskim uprazhneniyam. Gimnastika: Uchebnik dlya institutov fiz. kul'tury. M.: Fizkul'tura i sport, 45-47. (in Russian)

Verkhoshanskiy, Yu.V. (1988). Osnovy spetsial'noy fizicheskoy podgotovki sportsmenov. M.: Fizkul'tura i sport, 331. (in Russian)

D’yachkov, V.M. (1966). Metody sovershenstvovaniya v tekhnike dvizheniy kvalifitsirovannykh sportsmenov. Puti sovershenstvovaniya sportivnogo masterstva. M.: Fizkul'tura i sport, 3-22. (in Russian) 
Menkhin, Yu.V. (1969). Silovaya podgotovka gimnastov. M.: Fizkul'tura i sport, 87. (in Russian)

Maznichenko, V.D. (1976). Obuchenie dvizheniyam. Teoriya $i$ metodika fizicheskogo vospitaniya: Uchebnik dlya institutov fizicheskoy kul'tury. M.: Fizkul'tura i sport, 166-167. (in Russian)

Shlemin, A.M., \& Petrov, P.K. (1977). Sistema podgotovki yunykh gimnastov: Metodicheskoe posobie dlya studentov GTsOLIFKa. M., 97. (in Russian)

Shlemin, A.M. (1968). Issledovanie protsessa formirovaniya dvigatel'noy funktsii u detey i podrostkov (na materiale gimnastiki): Dis. ... d-ra ped. nauk: 13.00.04. M. (in Russian)
Yananis, S.V. (1969). Obuchenie dvizheniyam. Teoriya $i$ metodika fizicheskogo vospitaniya: Uchebnik dlya uchashchikhsya srednikh fizkul'turnykh uchebnykh zavedeniy. M.: Fizkul'tura i sport, 99-106. (in Russian)

Khudolii, O. (1985). Effektivnost' obucheniya dvizheniyam gimnastov 8-10 let pri razlichnom cheredovanii nagruzok. Teoriya i praktika fiz.kul'tury, (1), 25. (in Russian)

Orlov, A.K. (1969). Matematicheskoe modelirovanie nekotorykh storon protsessa obucheniya fizicheskim uprazhneniyam (na osnove stokhasticheskoy modeli Busha i Mostellera): Avtoref. dis. ... kand.ped. nauk: 13.00.04. M.: 24. (in Russian)

\title{
ДИДАКТИКА: МЕТОДОЛОГІЧНА ОСНОВА МОТОРНОГО НАВЧАННЯ ДІТЕЙ І ПІДЛІТКІВ
}

\author{
Олег Худолій ${ }^{1 \mathrm{ABCD}}$, Сергій Єрмаков ${ }^{2 \mathrm{ABCD}}$, Павол Бартік ${ }^{3 \mathrm{ABCD}}$ \\ ${ }^{1}$ Харківський національний педагогічний університет імені Г. С. Сковороди \\ ${ }^{2}$ Гданський університет фізичного виховання і спорту \\ ${ }^{3}$ Університет Матея Беля
}

Авторський вклад: А - дизайн дослідження; В - збір даних; C - статаналіз; D - підготовка рукопису; Е - збір коштів

Реферат. Статья: 9 с., 4 табл., 4 рис., 37 джерел.

Мета дослідження - визначити вплив знань, які розглядаються як методологічна основа моторного навчання, на ефективність формування рухових навичок у дітей i підлітків.

Матеріал і методи. В експерименті прийняли участь юні гімнасти 7-13 років. На першому етапі - юні гімнасти 8 років (16 груп по 6 чоловік). На другому етапі - юні гімнасти 8 років (3 групи по 6 чоловік), юні гімнасти 13 років (дві групи по 6 чоловік). Для вирішення поставлених завдань були використані як філософські так і загальнонаукові методи дослідження, серед яких: діалектичний метод, системний підхід, моделювання, педагогічний експеримент організований за схемою факторного експерименту типу $2 \mathrm{k}$.

Результати. Позитивний ефект навчання залежить від послідовного рішення завдань навчання і раціонального застосування методів. На це вказує наступне, по-перше, сумарний вплив чинників сприяє зниженню кількості повторень на навчання перевороту в сторону юних гімнастів (на 23 повторення), по-друге, сума взаємодії збільшує тривалість процесу навчання на 9 повторень. Очевидно, що дослідження в ділянці декомпозиції завдань навчання може призвести до збільшення ефективності навчання в цілому.

Висновки. На побудову процесу навчання найбільше впливають висновки теорії функціональних систем (43\%, $p<0.001)$, теорії побудови рухів $(41 \%, p<0.001)$ та теорії управління усвоєнням знань, формуванням дій і понять $(2,6 \%, p<0.05)$. Позитивний ефект навчання залежить від послідовного рішення завдань навчання і раціонального застосування методів.

Ключові слова: моторне навчання, методологічна основа, діти, підлітки.

\section{Information about the authors:}

Khudolii Oleg: khudolii.oleg@gmail.com; http://orcid.org/0000-0002-5605-9939; H. S. Skovoroda Kharkiv National Pedagogical University, Department of Theory and Methodology of Physical Education, Alchevskikh St, 29, Kharkiv, 61002, Ukraine.

Iermakov Sergii: sportart@gmail.com; http://orcid.org/0000-0002-5039-4517; Gdansk University of Physical Education and Sport, Department of Sports, Kasimir Gorskogo St, 1, 80-336 Gdansk, Poland.

Bartík Pavol: pavol.bartik@umb.sk; https://orcid.org/0000-0002-2087-7876; Department of Physical Education and Sports, Matej Bel University. Tajovského 40, 97401 Banská Bystrica, Slovakia.

Cite this article as: Khudolii, O., Iermakov, S., \& Bartik, P. (2020). Didactics: Methodological Basis of Motor Learning in Children and Adolescents. Journal of Learning Theory and Methodology, 1(1), 5-13. https://doi.org/10.17309/jltm.2020.1.01

Received: 27.04.2020. Accepted: 20.06.2020. Published: 30.06.2020

This work is licensed under a Creative Commons Attribution 4.0 International License (http://creativecommons.org/licenses/by/4.0). 